\title{
Article \\ Heterologous Expression and Characterization of a Ferulic Acid Esterase from Aspergillus aculeatus with Potential Use in Sunflower Seed Processing
}

\author{
Wenbin Zhang *(D), Jieyu Wang, Yuechen Liu and Juncai Leng $\mathbb{1}$
}

Citation: Zhang, W.; Wang, J.; Liu, Y.; Leng, J. Heterologous Expression and Characterization of a Ferulic Acid Esterase from Aspergillus aculeatus with Potential Use in Sunflower Seed Processing. Appl. Sci. 2021, 11, 4453. https://doi.org/10.3390/ app11104453

Academic Editor: Antonio Valero

Received: 21 April 2021

Accepted: 11 May 2021

Published: 13 May 2021

Publisher's Note: MDPI stays neutral with regard to jurisdictional claims in published maps and institutional affiliations.

Copyright: (c) 2021 by the authors. Licensee MDPI, Basel, Switzerland. This article is an open access article distributed under the terms and conditions of the Creative Commons Attribution (CC BY) license (https:/ / creativecommons.org/licenses/by/ $4.0 /)$.
School of Food Science and Technology, Jiangnan University, Wuxi 214122, China; 18861820867@163.com (J.W.); Ayn.liu@mdlz.com (Y.L.); lengjuncai@163.com (J.L.)

* Correspondence: wbzhang@jiangnan.edu.cn; Tel.: +86-139-1236-0161

\begin{abstract}
Hydrolytic activity for chlorogenic acid (CGA) has been recognized as an important side activity of some types of ferulic acid esterases. The purpose of this work was to enhance the efficient expression of ferulic acid esterase (FAE) and to explore its application in the processing of sunflower seed. Two novel FAEs from Aspergillus aculeatus (AaSD14) were expressed in genetically engineered $E$. coli BL21 (DE3), and their properties, including temperature, $\mathrm{pH}$, metal ions and substrate specificity, were characterized after purification. Competitive CGA hydrolysis activity was observed in these recombined ferulic acid esterases (reFAEs) with reFAE1 of $246.37 \mathrm{U} / \mathrm{g}$ and reFAE2 of $340.95 \mathrm{U} / \mathrm{g}$, which were 56.6 and 78.4 times higher than that of the wild strain $(4.35 \mathrm{U} / \mathrm{g})$, respectively. Meanwhile, the fermentation cycle was greatly shortened to $2.0 \mathrm{~d}$. These reFAEs were recognized as type C FAE through substrate specificity assays. Treatment of sunflower seed protein (SSP) using reFAE2 resulted in a remarkable color change, from green to milk-white, confirming the activity of CGA biodegradation. Therefore, it shows certain potential in the processing of sunflower seed and other related foodstuffs.
\end{abstract}

Keywords: Aspergillus aculeatus; chlorogenic acid; ferulic acid esterase; enzyme properties; sunflower seed

\section{Introduction}

Sunflower seeds are not only an important source of oil, but also a high-quality source of protein, which have the advantages of few anti-nutritional factors, low allergenicity, reasonable and balanced amino acid (AA) composition, etc. The protein content of sunflower seed is between $20 \%$ and $30 \%$, and its proper utilization can effectively alleviate the protein resource shortage [1]. After enzymatic sunflower seeds oil extraction, the alkalisoluble acid precipitation method is usually used to extract sunflower seeds protein (SSP) in the byproduct. However, there is abundant content of chlorogenic acid (CGA) in the by-product [2]. Under high $\mathrm{pH}$ conditions, the oxidatively polymerized CGA dimers tend to covalently bind to the polar groups of the protein, thereby generating green quinones [3] and affecting the sensory quality, functional properties and nutritional value of SSP [4-6]. This is the reason why SSP has been regarded as waste or low valuable animal feed, leading to financial loss and low utilization. CGA is an ester formed by the condensation of a molecule of caffeic acid and a molecule of quinic acid [7]. It is widely found in natural plants, such as sunflower seeds, eucommia, coffee beans and potatoes [8-10]. The CGA content in sunflower seeds can reach $71.4 \%$ of the total phenolic content in sunflower seeds and play a critically negative role in protein quality.

In view of the above situation, the removal of CGA by physical and chemical methods in the initial stage was not able to completely remove all CGA in SSP, and the unacceptable green color still existed after treatment [11]. The enzyme biodegradation is becoming an emerging way to eliminate hazardous substances in food byproducts. An Aspergillus 
strain SD14 was isolated from CGA-rich soil, which could produce an enzyme with CGA hydrolytic activity. Whole genome sequencing (WGS) is the individual genome sequencing of species with unknown genome sequences, which can detect all the genetic information in the genome [12]. The whole genome sequencing analysis showed that the Aspergillus strain SD14 is a strain of Aspergillus aculeatus, and the ferulic esterase is an enzyme capable of hydrolyzing CGA. Two genes encoding ferulic esterase were also annotated. This is consistent with some previous reports stating that some types of ferulic esterase can hydrolyze CGA [13-15]. However, in previous reports, CGA was only used as one of the substrates to react in the specific analysis of ferulic acid esterase (FAE), and very little attention has been paid to further practical application research. Because of its low enzyme activity $(4.35 \mathrm{U} / \mathrm{g})$ and long fermentation cycle $(11 \mathrm{~d})$, the wild ferulic esterase from AaSD14 was difficult to apply in the food industry. There is an urgent need to obtain efficient expression of engineering bacteria, by means of genetic engineering, to shorten fermentation time, to reduce fermentation cost, and to further improve CGA hydrolysis activity.

In the present research, we aimed to express these two novel genes (GME3292 and GME11122) encoding FAE efficiently in engineered E. coli BL21 (DE3), and to disclose the possibility of their heterogeneous expression. The recombined ferulic acid esterases (reFAEs) were characterized and applied to confirm its CGA hydrolysis activity. To the best of our knowledge, this is the first study in which ferulic esterase has been used in an attempt to remove CGA from SSP.

\section{Materials and Methods}

\subsection{Chemicals and Substrates}

AaSD14 was preserved in the Culture and Information Center of Industrial microorganisms of China Universities (Wuxi, China), numbered as F0920 and obtained by screening bacteria in our laboratory. All chemicals were purchased in the required purity grade from Shanghai Sangon Biology Co., Ltd. (Shanghai, China), Dalian Takara Co., Ltd. (Dalian, China), and British OXOID Co., Ltd. (Basingstoke, UK).

\subsection{Coding Sequence Analysis}

The DNA sequencing of AaSD14 was carried out by using third-generation singlemolecule sequencing technology (BGI, Inc. (Shenzhen, China)). The function of the genes was predicted by KEGG at https://www.kegg.jp/ (access dated 12 May 2021). Sequence similarity searches were performed with the BLAST 2.0 program. Amino acid (AA) sequence alignments of FAEs with proteins were performed with the CLUSTALW and ESPript 3.0.

\subsection{Expression of Wild Type C (WTC) FAE}

The AaSD14 was inoculated into PDA liquid medium and was shaken at $30{ }^{\circ} \mathrm{C}$, $160 \mathrm{r} / \mathrm{min}$, for $24 \mathrm{~h}$. The seed culture was inoculated at $5 \%$ inoculum, and the same conditions were used for a 10-d fermentation. At the end, the supernatant was obtained by centrifugation $\left(15 \mathrm{~min}\right.$ at $\left.4{ }^{\circ} \mathrm{C}, 14,400 \times g\right)$. The purification of WTC FAE was based on the method of Zhang et al. [11].

\subsection{Production of reFAEs in E. coli BL21}

E. coli BL21 was used for heterologous expression of the gene that encoded FAE from AaSD14. The genome of AaSD14 was used for PCR amplification as a template. According to the two sequences of annotated FAE named GME3292 and GME11122, primer pairs F1/R1 and F2/R2 were designed for their amplification, respectively. The two fragments were double digested with Hind III and Xho I and then ligated with pET28a (+), which were treated with the same restriction endonucleases to generate recombinant vectors, respectively. The successful recombinant vectors were transformed into E. coli BL21 (DE3). 


\subsection{Optimization of Induction Conditions}

The optimal conditions were explored in four aspects including induction timing $\mathrm{OD}_{600}(0.3 \sim 1.8)$, inducer concentration $(0.01 \sim 0.1 \mathrm{mmol} / \mathrm{L})$, induction duration $(4 \sim 24 \mathrm{~h})$ and induction temperature $\left(15 \sim 37^{\circ} \mathrm{C}\right)$. The maximum enzyme activity was recorded as $100 \%$ and the relative enzyme activity under different conditions was calculated and determined.

\subsection{Separation and Purification of reFAEs}

The cell pellets obtained after centrifugation were washed 3 times with $20 \mathrm{mmol} / \mathrm{L}$ phosphate buffer ( $\mathrm{pH} 7.4)$, then resuspended with $50 \mathrm{~mL}$ binding solution $(20 \mathrm{mmol} / \mathrm{L}$ $\mathrm{NaH}_{2} \mathrm{PO}_{4}-\mathrm{Na}_{2} \mathrm{HPO}_{4}, 10 \mathrm{mmol}$ imidazole, $50 \mathrm{mmol} \mathrm{NaCl}$, (pH 7.4)) for ultrasonic wall breaking. The ultrasonic treatment was carried out for $8 \mathrm{~min}$ with treatment of $5 \mathrm{~s}$ plus an interval of $5 \mathrm{~s}$ in an ice water bath, and the ultrasonic power was $360 \mathrm{~W}$. The cell crushing fluid was centrifuged at $4{ }^{\circ} \mathrm{C}, 14,400 \times \mathrm{g}$, for $15 \mathrm{~min}$ and the supernatant was recovered as crude enzyme solution.

The reFAEs were purified by Ni-NTA (Sangon Co., Ltd. (Shanghai, China)) affinity chromatography His Trap ${ }^{\mathrm{TM}} \mathrm{HP}\left(0.7 \times 2.5 \mathrm{~cm}^{2}\right)$ at a flow rate of $1 \mathrm{~mL} / \mathrm{min}$. Buffer solution of $20 \mathrm{mmol} / \mathrm{L}$ phosphate ( $\mathrm{pH} 7.4$ ) was used for dialysis of the collected samples at $4{ }^{\circ} \mathrm{C}$ The purification was monitored using SDS-PAGE analysis (12\% resolving gel, $5 \%$ stacking gel) according to Yang et al. [16].

\subsection{Activity Assay}

The determination method of enzyme activity and definition of the enzyme activity unit were conducted according to Zhang et al. [11].

\subsection{Biochemical Characterization of reFAEs}

The effect of temperature $\left(20 \sim 70{ }^{\circ} \mathrm{C}\right), \mathrm{pH}(3 \sim 10), 5 \mathrm{mmol} / \mathrm{L}$ metal ions (EDTA, $\mathrm{Na}^{+}$, $\left.\mathrm{K}^{+}, \mathrm{Ca}^{2+}, \mathrm{Mn}^{2+}, \mathrm{Mg}^{2+}, \mathrm{Fe}^{2+}, \mathrm{Zn}^{2+}, \mathrm{Cu}^{2+}, \mathrm{Al}^{3+}, \mathrm{Fe}^{3+}\right)$ and kinetic parameters $\left(\mathrm{K}_{\mathrm{m}}\right)$ of the reFAEs were determined as described by Song et al. [17].

\subsection{Substrate Specificity}

According to the method of Dilokpimol et al. [18], the purified reFAEs were tested to establish the hydrolytic activity of the typical substrates Methyl ferulate (MFA), Methyl caffeate (MCA), Methyl succinate (MSA), Methyl $p$-coumarate (MpCA) and Chlorogenic acid (CGA), as well as to determine the substrate specificity.

\subsection{Application Trials}

For application trials, crushed seeds (500 g) were incubated in $n$-hexane for $4 \mathrm{~h}$ at a solid/liquid ratio of $1: 5(\mathrm{w} / \mathrm{v})$ at $50{ }^{\circ} \mathrm{C}$ for defatting, and then they were dipped in $75 \%$ ethanol for $2 \mathrm{~h}$ under same conditions for polyphenol removal. The partially dephenolized sunflower seeds were dried at $40{ }^{\circ} \mathrm{C}$ and ground to 80 mesh as raw material. A portion of $100 \mathrm{~g}$ sunflower seed powder was incubated in $1 \mathrm{~L}$ deionized water with $1 \mathrm{~mL}$ purified reFAE2 $(0.5 \mathrm{U} / \mathrm{mL})$ at $60{ }^{\circ} \mathrm{C}$ and stirred for $3 \mathrm{~h}$ at $150 \mathrm{rpm}$. The control group received the same treatment except that no enzyme was added. Then, the two treatment solutions were adjusted to $\mathrm{pH} 9.0$ by $\mathrm{NaOH}$.

Color change was measured with a colorimeter according to the principle of CIE color space. Parameters $\mathrm{L}^{*}, \mathrm{a}^{*}$, and $\mathrm{b}^{*}$ indicate the intensity of lightness, redness, and yellowness of the sample, respectively [19].

\subsection{Statistical Analysis}

All experiments were carried out in triplicate, and each result was expressed as the mean \pm standard deviations. The differences between groups were tested by one-way ANOVA and Duncan's multiple range tests (SPSS version 19.0) with the level of statistical significance set at $p<0.05$. 


\section{Results and Discussion}

\subsection{Sequence Comparison to Known Esterases}

The sequence analysis revealed that there were two open reading frames (ORFs), which could both encode the FAEs. These two ORFs consisted of $1500 \mathrm{bp}$ and $1569 \mathrm{bp}$, thus encoding 500 and 523 amino acids (AAs), respectively. The amino acid alignment of reFAEs with other FAEs are presented in Figure 1. The deduced amino acid sequence of reFAEs was used to perform a BLAST search in the National Center for Biotechnology Information (NCBI) and SwissProt databases. It revealed a relative similarity between reFAEs and other FAEs, including alignment of the amino acid sequences among reFAE1, reFAE2, and other FAEs: AofaeB from Aspergillus oryzae (Genbank: PDB: 3WMT_B) [20] (28\% and $32 \%$ identity, respectively), AnFaeB from Aspergillus niger (Genbank: UniProtKB/SwissProt: Q8WZI8.1) [21] (29\% and 30\% identity, respectively), AN1772.2 from Aspergillus nidulans FGSC A4 (Genbank: UniProtKB/Swiss-Prot: Q5B2G3.1) [22] (28\% and 32\% identity, respectively), and FofaeC from Fusarium oxysporum (GenBank: SCN69328.1) [23] (29\% and $31 \%$ identity, respectively).

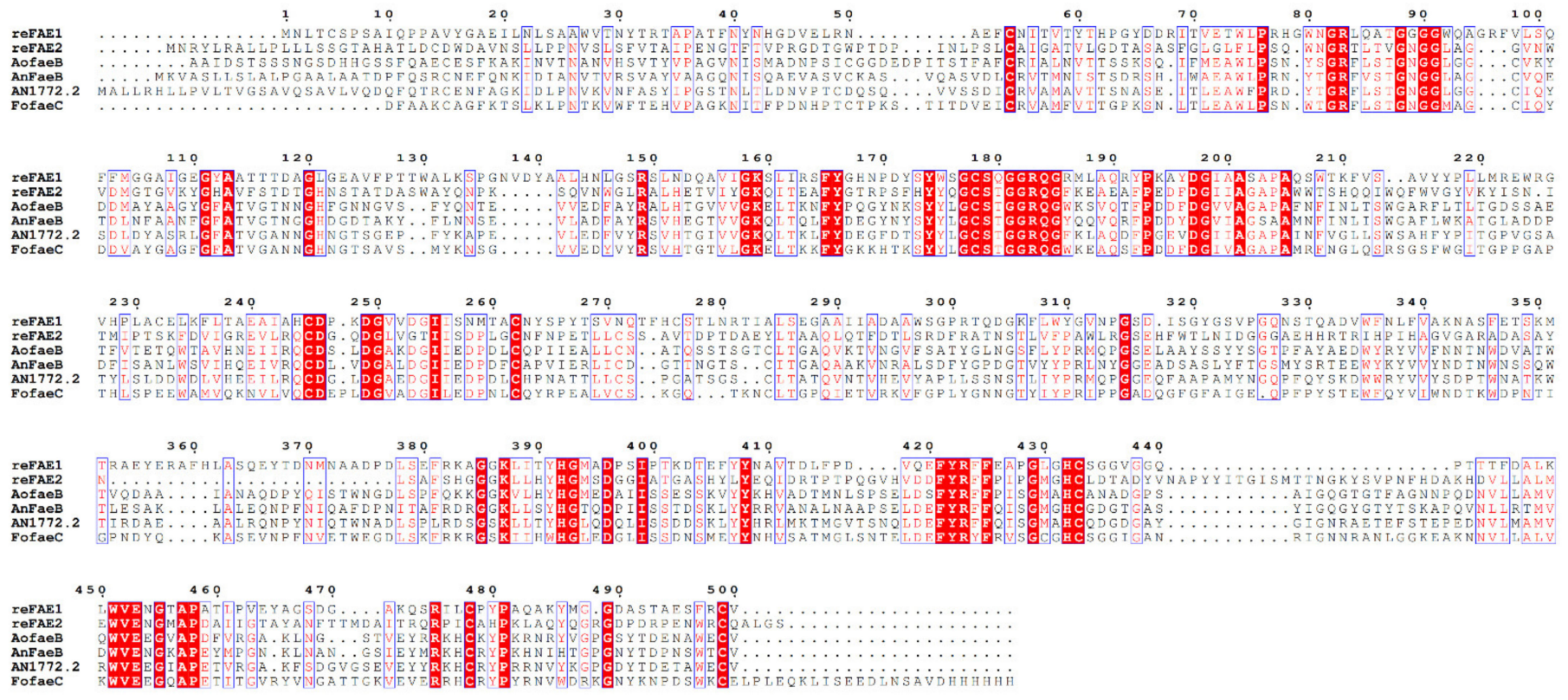

Figure 1. Alignment of the amino acid sequences among reFAE1, reFAE2, and other FAEs. The strictly conserved residues are demonstrated by white characters with red boxes, red characters denote the residues with high similarity in each group. The residues with high similarity across the groups are boxed in blue frames.

\subsection{Optimal Conditions for the Expression of Recombinant Vectors in E. coli}

The pET28a (+) vector contains the T7/lacl promoter, without induction, which was silenced in E. coli BL21 (DE3) host bacteria. The expression level of the reFAE was mainly affected by the inducer concentration, $\mathrm{OD}_{600}$, temperature and duration. Then, the optimal conditions were explored in terms of the four aspects of induction timing $\mathrm{OD}_{600}(0.3-1.8)$, inducer concentration (0.01-0.1 mmol/L), induction duration (4-24 h) and induction temperature $\left(15-37^{\circ} \mathrm{C}\right)$; one factor was changed and the others were constant. The result is shown in Figure 2. The optimal induction conditions were as follows: culture temperature of $37^{\circ} \mathrm{C}, \mathrm{OD}_{600}$ of 1.2 , IPTG concentration of $0.04 \mathrm{mmol} / \mathrm{L}$, induction temperature of $20^{\circ} \mathrm{C}$ and time of $20 \mathrm{~h}$. As for reFAE2, the final IPTG concentration was $0.02 \mathrm{mmol} / \mathrm{L}$, and other conditions were the same as reFAE1 (Figure 2). 

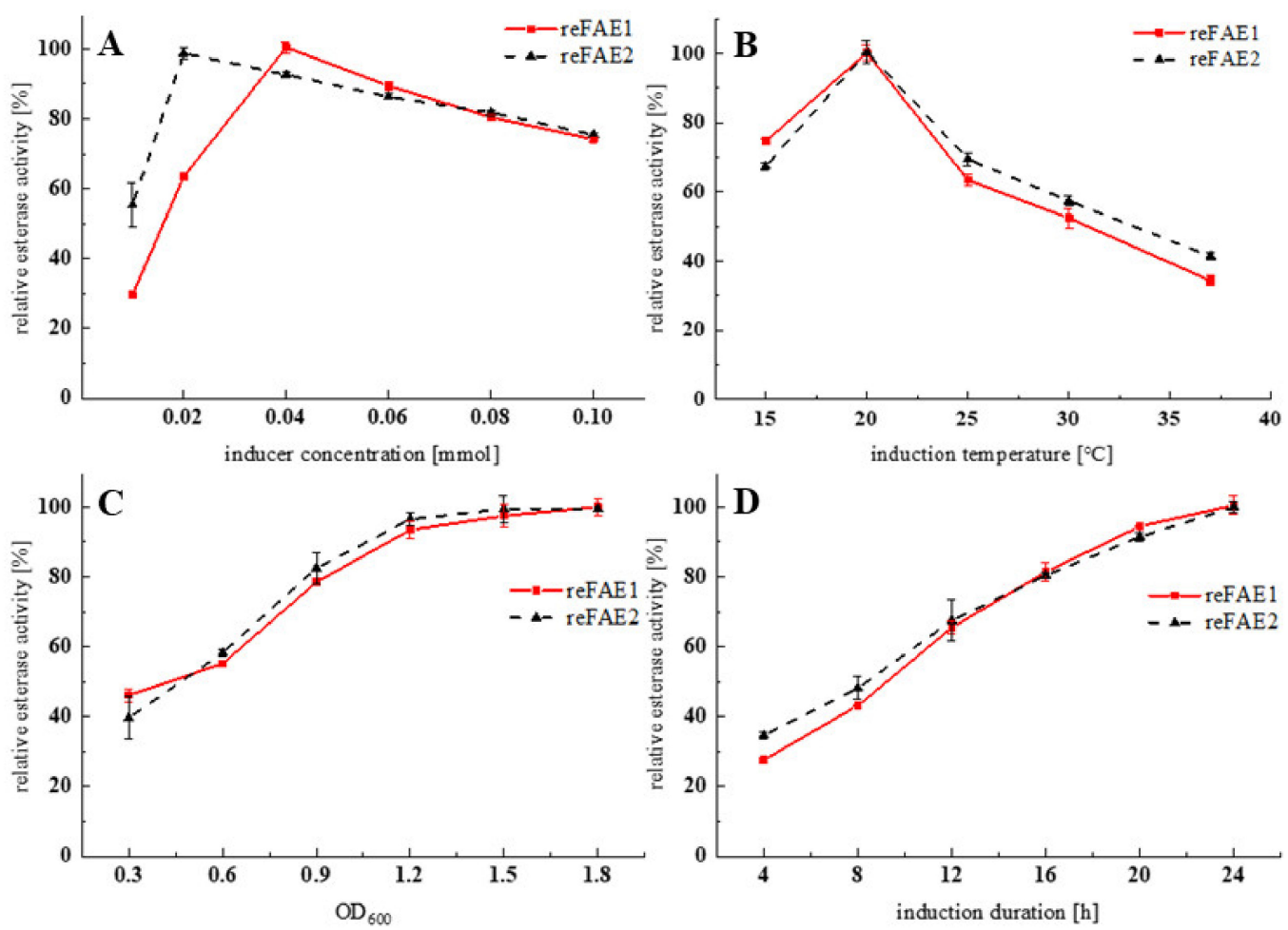

Figure 2. Optimization of induction conditions. (A) Optimal inducer concentration of reFAEs; (B) optimal induction temperature of reFAEs; (C) optimal $\mathrm{OD}_{600}$ value of reFAEs; (D) optimal induction duration of reFAEs.

\subsection{Purification of the reFAEs}

The vector pET28a used for the expression of reFAEs in E. coli contained a histidine tag (His-tag). Thus, the target proteins were isolated and purified by Ni-NTA (Sangon Co., Ltd. (Shanghai, China)) affinity chromatography, His Trap ${ }^{\mathrm{TM}} \mathrm{HP}\left(0.7 \times 2.5 \mathrm{~cm}^{2}\right)$.

SDS-PAGE electrophoresis (Figure 3) showed that reFAEs purified by Ni-NTA affinity chromatography obtained a single protein band with a size of $55 \mathrm{kDa}$, which was consistent with the theoretical relative molecular weights of $55.12 \mathrm{kDa}$ and $55.19 \mathrm{kDa}$. The CGA hydrolysis activity of the reFAEs was shown in Table 1. Compared with the UmChlE from U. maydis (237.6 U/g) [24], the CGA hydrolysis activity of reFAE2 was increased by $43 \%$.

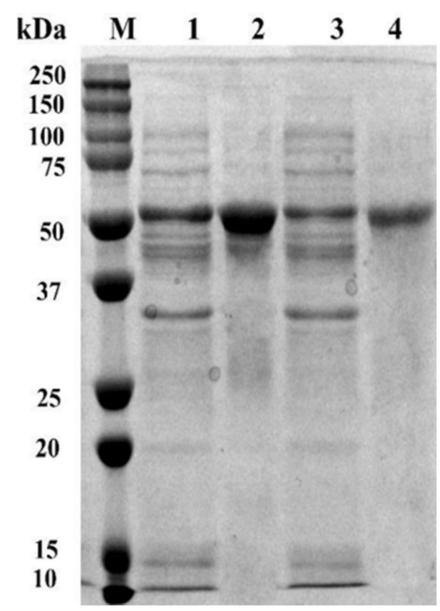

Figure 3. SDS-PAGE of purified recombinant proteins. (Lane M). Standard protein Marker; (Lane 1). GME3292-pET28a (+) cell disruption supernatant; (Lane 2). reFAE1 enzyme solution after purification; (Lane 3). GME11122-pET28a (+) cell disruption supernatant; (Lane 4). reFAE2 enzyme solution after purification. 
Table 1. Results of purification of recombinases.

\begin{tabular}{cccc}
\hline Esterases & Total Protein $(\mathbf{m g})$ & Total Activity (U) & Specific Activity (U/g) \\
\hline reFAE1 & $21.19 \pm 0.03^{\mathrm{b}}$ & $5.2238 \pm 0.03^{\mathrm{a}}$ & $246.37 \pm 0.03^{\mathrm{c}}$ \\
reFAE2 & $24.36 \pm 0.08^{\mathrm{b}}$ & $8.3055 \pm 0.02^{\mathrm{a}}$ & $340.95 \pm 0.04^{\mathrm{c}}$ \\
\hline
\end{tabular}

Different letters $(\mathrm{a}, \mathrm{b}, \mathrm{c})$ in the same column indicate significant differences at $p<0.05$.

The relative molecular mass of the reFAEs under non-denaturing conditions was determined with a Superdex 200 10/300 GL gel column. The molecular mass of reFAE1 was about 100-120 kDa, while that of reFAE2 was about 110-120 kDa. Furthermore, SDSPAGE electrophoresis showed that the relative molecular mass of reFAE1 and reFAE2 was 55 and $57 \mathrm{kDa}$, respectively. Therefore, it can be speculated that the reFAEs were composed of two homologous monomers. Similar results were found with the FAE in Aspergillus oryzae [20].

\subsection{Biochemical Characterization of reFAEs}

The effects of temperature on the CGA hydrolysis activity of purified reFAEs and WTC FAE were shown in Figure 4A. The hydrolysis activity of the three enzymes increased with the rise in temperature within a certain range, but the enzyme activity was inhibited after each optimum temperature. The reFAE1 and reFAE2 reached their maximum activity at $60^{\circ} \mathrm{C}$ and $50{ }^{\circ} \mathrm{C}$, respectively. This was in accordance with the reported optimum reaction temperature for FAE [14]. By comparing these three enzymes, it can be found that optimal temperature of reFAE2 for CGA hydrolysis had been lowered by about $10^{\circ} \mathrm{C}$, indicating lower energy consumption and higher acceptability for industrial application.
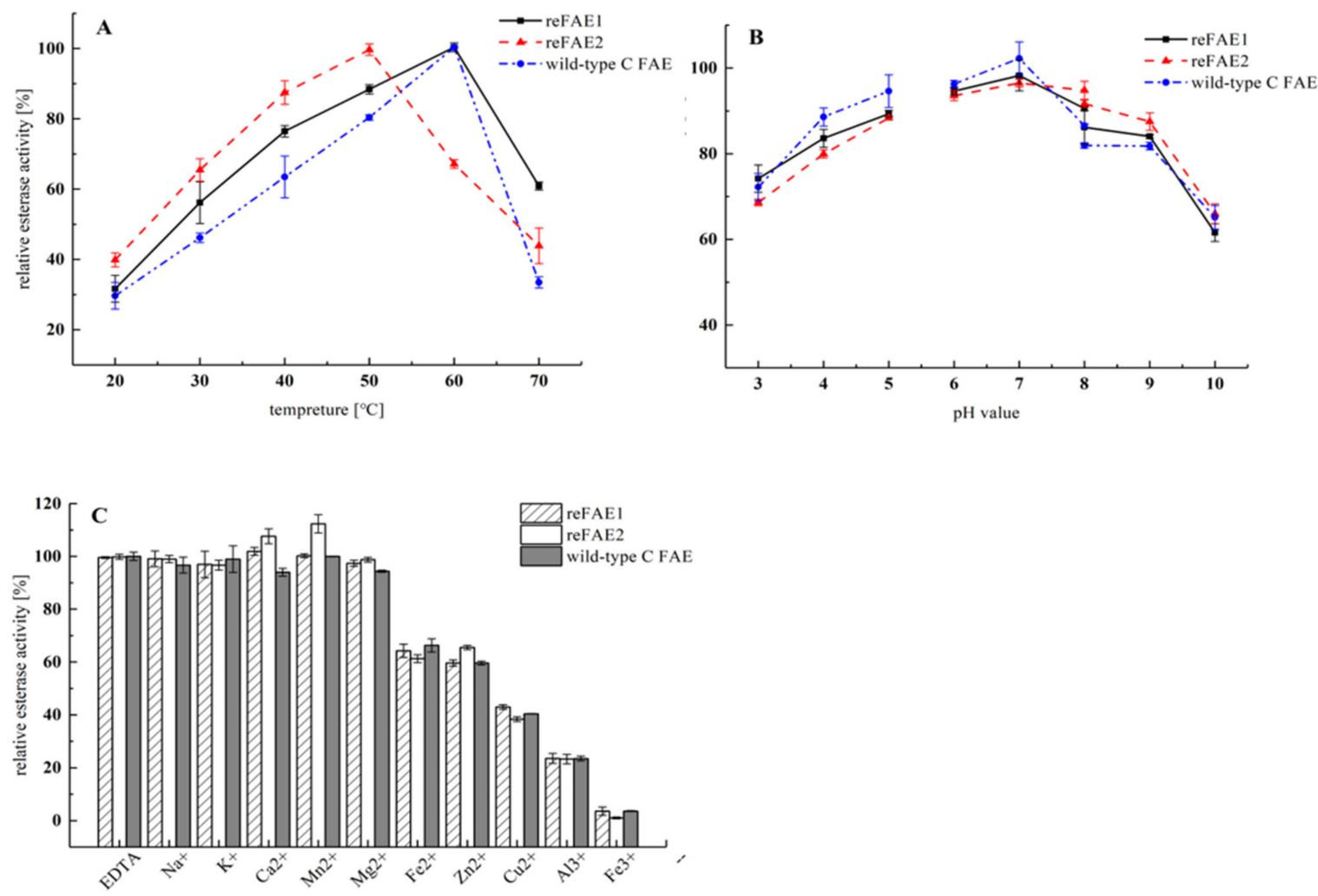

Figure 4. (A) Effect of temperature on the CGA hydrolysis activity of recombinant proteins and WTC FAE; (B) effect of $\mathrm{pH}$ on the CGA hydrolysis activity of recombinant proteins and WTC C FAE. For different $\mathrm{pH}$ conditions, different buffer solutions are used: sodium citrate buffer for $\mathrm{pH} 3-5$, phosphate buffer for $\mathrm{pH}$ 6-8, and glycine-NaOH buffer for $\mathrm{pH} 8-10$. (C) Effect of metal ions on the activity of recombinant proteins. 
When different $\mathrm{pH}$ values were applied to the reFAEs, the optimum $\mathrm{pH}$ of the purified reFAEs was equal to that from WTC at 7.0 (Figure 4B). When the $\mathrm{pH}$ was between 3.0 and 10.0 , their enzyme activity was stable, indicating that the range for application of reFAEs was wide.

Metal ions can chelate with the local functional groups of the enzyme protein, affecting its three-dimensional structure, and thereby changing the catalytic efficiency and stability of the enzyme. It was found that EDTA treatment had no effect on the activity of the WTC FAE and reFAEs (Figure 4C), and thus, it could be expected that there was no participation of divalent ions in the active site of the reFAEs [25]. The 10 metal ions used in the assay had different effects on the reFAE1, while $\mathrm{Mn}^{2+}$ and $\mathrm{Ca}^{2+}$ had a certain degree of activation effect on reFAE2, whose enzyme activity levels increased by about $8 \%$ and $12 \%$, respectively. The monovalent metal ions had an insignificant effect on the enzyme activity of WTC FAE, while the activity was significantly inhibited by the divalent ions $\mathrm{Zn}^{2+}, \mathrm{Cu}^{2+}$ and $\mathrm{Fe}^{2+}$. Among them, the activity of reFAE1 and reFAE2 decreased by $43 \%$ and $38 \%$, respectively, under the action of $\mathrm{Cu}^{2+}$. The trivalent metal ions $\mathrm{Al}^{3+}$ and $\mathrm{Fe}^{3+}$ had a strongly detrimental influence on enzyme activity, and the enzyme activities of the recombinases were almost completely lost after $\mathrm{Fe}^{3+}$ treatment. The above findings indicated that the reFAEs could hydrolyze CGA without the participation of specific metal ions. When applied in CGA hydrolysis, trivalent metal ions should be taken away for better performance of the recombinant proteins.

\subsection{Substrate Profile and Kinetic Parameters}

To investigate the substrate specificity of reFAEs, a comprehensive set of substrates was used for the hydrolytic activity assay. MFA, MCA, MSA and M $p$ CA were selected as substrates besides CGA. The reFAEs showed totally different substrate preferences (Table 2).

Table 2. Results of purification of esterases.

\begin{tabular}{ccc}
\hline \multirow{2}{*}{ Substrate } & \multicolumn{2}{c}{ Specific Activity (U/g) } \\
\cline { 2 - 3 } & reFAE1 & reFAE2 \\
\hline MFA & $8.90 \pm 0.01^{\mathrm{a}}$ & $12.86 \pm 0.28^{\mathrm{b}}$ \\
MCA & $433.35 \pm 0.68^{\mathrm{a}}$ & $583.66 \pm 1.03^{\mathrm{b}}$ \\
MSA & $14.21 \pm 0.08^{\mathrm{b}}$ & $7.13 \pm 0.05^{\mathrm{a}}$ \\
M $p$ CA & $258.97 \pm 0.16^{\mathrm{a}}$ & $294.58 \pm 0.82^{\mathrm{b}}$ \\
CGA & $246.37 \pm 0.02^{\mathrm{a}}$ & $340.95 \pm 0.04^{\mathrm{b}}$ \\
\hline
\end{tabular}

Different letters $(\mathrm{a}, \mathrm{b})$ in the same column indicate significant differences at $p<0.05$.

Based on the substrate specificity of the reFAEs and hydrolysis ability of MFA, MCA, MSA and M $p$ CA, it was preliminarily speculated that both reFAE1 and reFAE2 belonged to type C FAE [26,27]. The ability of the reFAEs to hydrolyze CGA was similar with that of $\mathrm{M} p \mathrm{CA}$, which could be attributed to the carbon chain length of the substrate molecule [20], the size of the substituent [28] and the loop structure of the enzyme molecule [29].

The value of $K_{m}$ can reflect the binding ability of the enzyme and substrate. The smaller the $K_{m}$ value, the stronger the affinity between enzyme and substrate. With CGA as substrate, the $\mathrm{Km}$ and Vmax of reFAE1 were $79.85 \mu \mathrm{mol}$ and $6.19 \mathrm{mmol} / \mathrm{mg} \cdot \mathrm{min}$, respectively; and the $\mathrm{Km}$ and Vmax of reFAE2 were $105.98 \mu \mathrm{mol}$ and $6.53 \mathrm{mmol} / \mathrm{mg} \cdot \mathrm{min}$, respectively. The $\mathrm{K}_{\mathrm{m}}$ of the recombinases was, in both cases, lower than other reported enzymes, which showed better affinity for CGA than others. For example, the $\mathrm{K}_{\mathrm{m}}$ values of B-type FAE, AoFaeB produced by Neurospora and two FAEB from Aspergillus niger for CGA were 180, 160 and $630 \mu \mathrm{mol}$, respectively $[12,13,20]$.

\subsection{Application of reFAE2 in SSP Solution}

CGA is easily oxidized to form green quinones in the protein extraction process, which binds to protein and affects the sensory quality of SSP. The green color of SSP is profoundly 
correlated with the high content of CGA [3]. After the reFAE2 treatment, the CGA in the sunflower seeds was completely hydrolyzed to produce caffeic acid, and the protein became milk-white, which greatly eliminated the green color of SSP (Table 3).

Table 3. The effect of reFAE2 on the color parameters and photographs of SSPs (A: Without enzymetreated solution of SSP; B: Enzyme-treated solution of SSP).

\begin{tabular}{ccccc}
\hline Sample & $\mathbf{L}^{*}$ & $\mathbf{a}^{*}$ & $\mathbf{b}^{*}$ & Appearance \\
\hline $\mathrm{A}$ & $53.61 \pm 1.32^{\mathrm{a}}$ & $-50.10 \pm 0.66^{\mathrm{a}}$ & $-24.32 \pm 0.27^{\mathrm{a}}$ & $\mathbf{1}$ \\
$\mathrm{B}$ & $87.75 \pm 1.24^{\mathrm{b}}$ & $20.62 \pm 0.72^{\mathrm{b}}$ & $32.14 \pm 0.32^{\mathrm{b}}$ & \\
\hline
\end{tabular}

Different letters $(\mathrm{a}, \mathrm{b})$ in the same column indicate significant differences at $p<0.05$.

Color change was measured with a colorimeter according to the principle of CIE color space. The instrument had been calibrated with a standard color plate (white). Parameters $L^{*}, a^{*}$, and $b^{*}$ indicate the intensity of lightness, redness and yellowness of the sample, respectively. After the enzyme treatment, the $\mathrm{a}^{*}$ of the SSP solution became positive, as compared to the negative $a^{*}$ without enzyme treatment. Meanwhile, the $b^{*}$ of the protein solution was significantly higher than that without enzyme treatment. The $\mathrm{L}^{*}$ of the SSP solution (87.75) after enzyme treatment was much higher than that before the enzyme treatment (53.61), illustrating that CGA hydrolysis significantly increased the brightness of the SSP solution. The change in color from green to milk-white increased the acceptability and nutritional value of SSP. Therefore, chances for SSP as an important protein source as well as general food ingredients were increased.

\section{Conclusions}

Two novel FAEs with CGA hydrolytic activity from Aspergillus aculeatus were heterologously expressed in E. coli, purified to homogeneity and biochemically characterized. The specific activity of reFAE1 and reFAE2 for CGA hydrolysis was higher than that of the wild strains, respectively. Meanwhile, the fermentation cycle was greatly shortened compared to the original wild strain. The optimum reaction conditions for reFAE1 and reFAE2 were determined in this study. According to substrate specificity assay, both reFAE1 and reFAE2 were recognized as type $C F A E$, possessing good thermostability and substrate affinity to CGA. With the addition of reFAE2, the color of SSP solution changed noticeably from green to milk-white. This indicated that reFAE2 had potential for application in sunflower processing or another type of processing related to CGA. In the future, the expression of these novel ferulic esterases in fungal microorganisms will be studied further in order to improve their expression efficiency.

Author Contributions: Conceptualization, W.Z. and J.W.; methodology, J.W. and Y.L.; writingoriginal draft preparation, J.W.; writing — review and editing, J.W. and J.L.; project administration, W.Z. and J.W. All authors have read and agreed to the published version of the manuscript.

Funding: This research was funded by the National Natural Science Foundation of China (31401635); the Key R\&D program of Jiangsu Province (SZ-YC2018010 and XZ-SZ 201805) and the National First-Class Discipline Program of Food Science and Technology (JUFSTR20180202).

Conflicts of Interest: The funders had no role in the design of the study; in the collection, analyses, or interpretation of data; in the writing of the manuscript, or in the decision to publish the results.

\section{References}

1. Wijayanti, I.; Ysa, Z.; Khotijah, L. The Evaluation of Sunflower Seed Meal as Protein Source in Lamb Ration. IOP Conf. Ser. Environ. Earth Sci. 2020, 478, 012028. [CrossRef]

2. Liang, S.; Were, L.M. Chlorogenic acid induced colored reactions and their effect on carbonyls, phenolic content, and antioxidant capacity in sunflower butter cookies. LWT Food Sci. Technol. 2018, 87, 16-22. [CrossRef] 
3. Zardo, I.; de Espíndola Sobczyk, A.; Marczak, L.D.F.; Sarkis, J. Optimization of Ultrasound Assisted Extraction of Phenolic Compounds from Sunflower Seed Cake Using Response Surface Methodology. Waste Biomass Valoris. 2017, 10, 33-44. [CrossRef]

4. Głowacka, R.; Górska, A.; Wirkowska-Wojdyła, M.; Wołosiak, R.; Majewska, E.; Derewiaka, D. The influence of brewing method on bioactive compounds residues in spent coffee grounds of different roasting degree and geographical origin. Int. J. Food Sci. Technol. 2019, 54, 3008-3014. [CrossRef]

5. Moon, J.K.; Yoo, H.S.; Shibamoto, T. Role of roasting conditions in the level of chlorogenic acid content in coffee beans: Correlation with coffee acidity. J. Agric. Food Chem. 2009, 57, 5365-5369. [CrossRef]

6. Tai, E.-S.; Hsieh, P.-C.; Sheu, S.-C. Effect of polygalacturonase and feruloyl esterase from Aspergillus tubingensis on demucilage and quality of coffee beans. Process. Biochem. 2014, 49, 1274-1280. [CrossRef]

7. Butiuk, A.P.; Adachi, O.; Hours, R.A. Yerba mate as a novel inducer for fungal chlorogenate hydrolase production. Biocatal. Agric. Biotechnol. 2015, 4, 327-334. [CrossRef]

8. De Luca, S.; Ciotoli, E.; Biancolillo, A.; Bucci, R.; Magri, A.D.; Marini, F. Simultaneous quantification of caffeine and chlorogenic acid in coffee green beans and varietal classification of the samples by HPLC-DAD coupled with chemometrics. Environ. Sci. Pollut. Res. Int. 2018, 25, 28748-28759. [CrossRef]

9. Siebert, M.; Berger, R.G.; Pfeiffer, F. Hydrolysis of chlorogenic acid in apple juice using a p-coumaryl esterase of Rhizoctonia solani. J. Sci. Food Agric. 2019, 99, 6644-6648. [CrossRef]

10. Wildermuth, S.R.; Young, E.E.; Were, L.M. Chlorogenic Acid Oxidation and Its Reaction with Sunflower Proteins to Form Green-Colored Complexes. Compr. Rev. Food Sci. Food Saf. 2016, 15, 829-843. [CrossRef]

11. Zhang, W.; Liu, Y.; Hu, M.; Yang, R. Preparation of high-quality sunflower seed protein with a new chlorogenic acid hydrolase from Aspergillus niger. Biotechnol. Lett. 2019, 41, 565-574. [CrossRef]

12. Duggett, N.; Abuoun, M.; Randall, L.; Horton, R.; Anjum, M.F. The importance of using whole genome sequencing and extended spectrum beta-lactamase selective media when monitoring antimicrobial resistance. Sci. Rep. 2020, 10, 19880. [CrossRef]

13. Crepin, V.F.; Faulds, C.B.; Connerton, I.F. A non-modular type B feruloyl esterase from Neurospora crassa exhibits concentrationdependent substrate inhibition. Biochem. J. 2003, 370, 417-427. [CrossRef]

14. Levasseur, A.; Benoit, I.; Asther, M.; Asther, M.; Record, E. Homologous expression of the feruloyl esterase B gene from Aspergillus niger and characterization of the recombinant enzyme. Protein Expres. Purif. 2004, 37, 126-133. [CrossRef]

15. Koseki, T.; Handa, H.; Watanabe, Y.-Y.; Ohtsuka, M.; Shiono, Y. An unusual feruloyl esterase from Aspergillus oryzae: Two tryptophan residues play a crucial role for the activity. J. Mol. Catal. B Enzym. 2016, 133, S560-S568. [CrossRef]

16. Yang, L.; Zhou, N.; Tian, Y. Purification, characterization, and biocatalytic potential of a novel dextranase from Chaetomium globosum. Biotechnol. Lett. 2018, 40, 1407-1418. [CrossRef]

17. Song, J.; Kim, S.Y.; Kim, D.H.; Lee, Y.S.; Sim, J.S.; Hahn, B.S.; Lee, C.M. Characterization of an inhibitor-resistant endo-1,4-betamannanase from the gut microflora metagenome of Hermetia illucens. Biotechnol. Lett. 2018, 40, 1377-1387. [CrossRef]

18. Dilokpimol, A.; Makela, M.R.; Aguilar-Pontes, M.V.; Benoit-Gelber, I.; Hilden, K.S.; de Vries, R.P. Diversity of fungal feruloyl esterases: Updated phylogenetic classification, properties, and industrial applications. Biotechnol. Biofuels 2016, 9, 231. [CrossRef]

19. Durmus, D. CIELAB color space boundaries under theoretical spectra and 99 test color samples. Color Res. Appl. 2020, 45, 796-802. [CrossRef]

20. Koseki, T.; Hori, A.; Seki, S.; Murayama, T.; Shiono, Y. Characterization of two distinct feruloyl esterases, AoFaeB and AoFaeC, from Aspergillus oryzae. Appl. Microbiol. Biotechnol. 2009, 83, 689-696. [CrossRef]

21. Kroon, P.; Faulds, C.; Williamson, G. Purification and characterization of a novel esterase induced by growth of Aspergillus niger on sugar-beet pulp. Biotechnol. Appl. Biochem. 1996, 23, 255-262. [CrossRef] [PubMed]

22. Galagan, J.E.; Calvo, S.E.; Cuomo, C.; Ma, L.J.; Wortman, J.R.; Batzoglou, S.; Lee, S.I.; Bastuerkmen, M.; Spevak, C.C.; Clutterbuck, J. Sequencing of Aspergillus nidulans and comparative analysis with A. fumigatus and A. oryzae. Nature 2005, 438, 1105-1115. [CrossRef] [PubMed]

23. Moukouli, M.; Topakas, E.; Christakopoulos, P. Cloning, characterization and functional expression of an alkalitolerant type C feruloyl esterase from Fusarium oxysporum. Appl. Microbiol. Biotechnol. 2008, 79, 245-254. [CrossRef] [PubMed]

24. Nieter, A.; Haase-Aschoff, P.; Kelle, S.; Linke, D.; Krings, U.; Popper, L.; Berger, R.G. A chlorogenic acid esterase with a unique substrate specificity from Ustilago maydis. Appl. Environ. Microbiol. 2015, 81, 1679-1688. [CrossRef]

25. Wang, L.; Zhang, R.; Ma, Z.; Wang, H.; Ng, T. A feruloyl esterase (FAE) characterized by relatively high thermostability from the edible mushroom Russula virescens. Appl. Biochem. Biotechnol. 2014, 172, 993-1003. [CrossRef]

26. Benoit, I.; Danchin, E.G.; Bleichrodt, R.J.; de Vries, R.P. Biotechnological applications and potential of fungal feruloyl esterases based on prevalence, classification and biochemical diversity. Biotechnol. Lett. 2008, 30, 387-396. [CrossRef]

27. Udatha, D.B.; Kouskoumvekaki, I.; Olsson, L.; Panagiotou, G. The interplay of descriptor-based computational analysis with pharmacophore modeling builds the basis for a novel classification scheme for feruloyl esterases. Biotechnol. Adv. 2011, 29, 94-110. [CrossRef]

28. Wong, D.W.S.; Chan, V.J.; Liao, H. Metagenomic discovery of feruloyl esterases from rumen microflora. Appl. Microbiol. Biotechnol. 2019, 103, 8449-8457. [CrossRef]

29. Uraji, M.; Tamura, H.; Mizohata, E.; Arima, J.; Wan, K.; Ogawa, K.; Inoue, T.; Hatanaka, T. Loop of Streptomyces Feruloyl Esterase Plays an Important Role in the Enzyme's Catalyzing the Release of Ferulic Acid from Biomass. Appl. Environ. Microbiol. $2018,84$. [CrossRef] 